\title{
Reply to the letter from A. Zorzi and D. Corrado. Rhythm analysis with an AED in an unconscious athlete
}

\author{
N. M. Panhuyzen-Goedkoop ${ }^{1,2,3} \cdot$ H. J. Wellens ${ }^{4} \cdot$ J. J. Piek ${ }^{1}$
}

Published online: 8 March 2018

(c) The Author(s) 2018. This article is an open access publication.

We thank our colleagues Zorzi and Corrado for their comments on the problem of delayed on-site cardiopulmonary resuscitation and defibrillation with an AED when the athlete loses his/her consciousness during exercise [1, 2]. Those problems are well illustrated in their video from episodes of sudden cardiac arrest (SCA) in 22 athletes. They correctly stress the confusion created when agonal breathing and limb movements may mistakenly be interpreted that the person is still alive [1]. We agree with Zorzi and Corrado that the immediate use of an AED would allow recognition of a cardiac cause of unconsciousness, i. e. ventricular tachycardia or fibrillation or asystole [1]. Indeed, immediate cardiac massage and rhythm analysis with an AED should be performed as soon as possible in an unexpected unconscious athlete.
Open Access This article is distributed under the terms of the Creative Commons Attribution 4.0 International License (http:// creativecommons.org/licenses/by/4.0/), which permits unrestricted use, distribution, and reproduction in any medium, provided you give appropriate credit to the original author(s) and the source, provide a link to the Creative Commons license, and indicate if changes were made.

\section{References}

1. Zorzi A, Corrado D. Cardiac arrest during sports activity is difficult to recognize? Let's the AED do the job! Neth Heart J. 2018; doi:https://doi.org/10.1007/s12471-018-1097-1.

2. Panhuyzen-Goedkoop NM, Wellens HJ, Piek JJ. Early recognition of sudden cardiac arrest in athletes during sports activity. Neth Heart J. 2018;26:21-5.
N. M. Panhuyzen-Goedkoop

nicolepanhuyzen@me.com

1 AMC Heart Center, Academic Medical Center, Amsterdam, The Netherlands

2 Sports Medical Center Papendal Arnhem, Arnhem, The Netherlands

3 Radboud University Medical Center, Nijmegen, The Netherlands

4 The Cardiovascular Research Center, Maastricht, The Netherlands 